\section{ТРУД В ЭТНИЧЕСКОЙ КУЛЬТУРЕ КОЧЕВНИКОВ ПОСТСОЦИАЛИЗМА (НА ПРИМЕРЕ БУРЯТ, КАЛМЫКОВ, ТУВИНЦЕВ)}

\author{
Любовь Б. Четырова \\ Самарский национальный \\ исследовательский университет \\ им. С. П. Королева, Российская \\ Федерация
}

\section{LABOR IN POST-SOCIALIST ETHNIC CULTURE: THE CASES OF BURYATS, KALMYKS AND TUVANS}

\author{
Lyubov B. Chetyrova \\ Samara National \\ Research University, \\ Russian Federation
}

В статье рассматривается вопрос о феномене труда в культуре тюрко-монголов - бурят, калмыков, тувинцев. Обосновывается положение о типологическом единстве трудовой культуры этих народов, связанных единством тюрко-монгольского этногенеза. Анализируется опыт трансформации их трудовой культуры в ходе форматирования данных этносов в период реализации советской модернизации. Ключевые моменты в развитии трудовой культуры выделяются на основании этапов формирования этносов и их трансформации: период существования Монгольской империи; вхождение в состав Российской империи; советский период. Показано, что в истории трудовой культуры этих этносов конкурирующими были две основные модели труда: труд кочевника-скотовода, тесно связанный с ратным делом, и труд земледельца. В результате успешной реализации советской модернизации в большинстве регионов их проживания сформировалась модель труда оседло живущего работника.

Рассматривается, как происходило изменение моделей и образов труда в период социальных

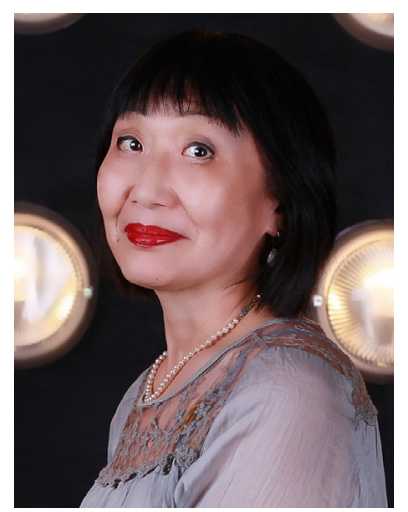

The article analyzes the phenomenon of labor in the culture of three Turkic-Mongol peoples Buryats, Kalmyks, and Tuvans. The author proves the typological unity of their labor culture. These peoples were unified by the TurkicMongolian ethnogenesis, as well as by the common experience of being reformatted as Socialist nations in the course of Soviet modernization.

The key moments in the development of their labor cultures can be outlined in accordance with the stages of their ethnicity formation and their transformation into Socialist nations: the period of the Mongol Empire; accession into the Russian Empire; the Soviet period. Two basic models of labor were competing within the labor history of these ethnic groups: that of a nomadic livestock breeder (and, connectedly, a warrior) and that of an agricultural worker. Finally, the labor model of a sedentary living worker has appeared in the course of Soviet modernization.

\footnotetext{
Четырова Любовь Борисовна - доктор философских наук, профессор кафедры философии Самарского национального исследовательского университета им. С. П. Королева. Адрес: 443086, Россия, г. Самара, Московское шоссе, д. 34. Тел.: +7 (846) 337-99-54. Эл. адрес: chetyrova@gmail.com

Chetyrova Lyubov Borisovna, Doctor of Philosophy, Professor, Department of Philosophy, S. P. Korolyov Samara National Research University. Postal address: 34 Moskovskoye shosse, 443086 Samara, Russian Federation. Tel.: +7 (846) 337-99-54. E-mail: chetyrova@gmail.com
} 
трансформаций, начавшихся в начале 1990-х годов. Экономический коллапс, в который оказалось ввергнуто постсоветское общество, запустил разные стратегии выживания, в числе которых было обращение к архаике в этнических регионах. В трудовой сфере такими стратегиями стали не только возрождение пастбищного скотоводства, но и легализация шаманов, медлгчи, деятельность которых квалифицируется как трудовая, приносящая доход.

Ключевые слова: труд; модели труда; кочевники; кочевая культура; тюрко-монголы; ратное дело; империя; пастбищное скотоводство; земледелие; шаман; советская модернизация; буряты; калмыки; тувинцы; экономическая культура
The article also considers how the change of labor models and images occurred during the period of social transformations that began in the early 1990s. The economic collapse of the postSoviet society helped elaborate various survival strategies, including a turn to the archaic in ethnic regions. Such labor strategies include the revival of pasture livestock breeding, the legalization of shamans and healers (medglchi), whose work is recognized as a source of legitimate income.

Keywords: work; labor models; nomads; nomadic culture; Turkic-Mongol peoples; military affairs; empire; pasture cattle breeding; agriculture; shaman; Soviet modernization; Buryats; Kalmyks; Tuvans; economic culture

\section{Введение}

До настоящего времени около 200 млн людей на планете занимаются пастбищным скотоводством. Производство мяса занимает $70 \%$ всех сельскохозяйственных земель или 30\% всей поверхности земли. В Амазонии сегодня 70\% прежде лесистых территорий ныне используются как пастбища для скота (Nierenberg, 2007: 24, Электр. ресурс). Производство и потребление мяса растут год от года (там же: 24, Электр. ресурс). Все это говорит о том, что не только животноводство, но и пастбищное скотоводство сегодня активно развиваются.

Для тюрко-монгольских народов пастбищное скотоводство испокон веков было главным видом хозяйственной деятельности. Несмотря на то, что в советский период развивались и доминировали совсем другие виды хозяйственной деятельности, скотоводство по-прежнему рассматривается как важный вид деятельности среди них. Российские тюрко-монгольские этносы, пройдя через горнило советской модернизации, стали нациями, представители которых являются образованными людьми, трудящимися в самых разных отраслях экономики. Успешно интегрируясь в современное общественное производство, руководствуясь современными моделями труда, данные этносы продолжают сохранять и следовать модели труда - пастбищному скотоводству. Согласно социологическим опросам, около $70 \%$ жителей Калмыкии поддерживают возрождение степного скотоводства (Бадмаев, 2007: 11). В последние десятилетия в этнических регионах растет число домохозяйств, в той или иной мере занимающихся скотоводством. Главной причиной возврата к прежней кочевой модели труда является, конечно, безработица на селе. Такая модель труда воспринимается людьми как исконная, архетипическая, выступающая как ресурс идентичности тюрко-монгола. Однако, если взглянуть на историю 
формирования моделей труда в культуре тюрко-монголов ретроспективно, то обнаружится, что далеко не все из указанных народов и далеко не всегда были кочевниками-скотоводами.

Целью статьи является исследование трансформаций моделей труда в культуре тюрко-монголов, начиная с раннего средневековья и вплоть до постсоциалистического периода.

\section{Символизм трудовой культуры кочевников}

Труд как действия, направленные на внешний мир и требующие физических усилий, конституирует, согласно А. Щюцу, повседневность (Шюц, 1988: 129-137). Признаками повседневного переживания и поведения являются отсутствие рефлексии, а также личностной вовлеченности в те или иные ситуации, типическое восприятие других и мотивов их действий. С этой точки зрения все виды практик у кочевников кодифицированы, исполняются в строгом соответствии с правилами и не подвергаются сомнению. К примеру, убой животных осуществляется строго по правилам, нарушение которых чревато негативными последствия для работника и его рода. Или перемещение женщины в пространстве юрты строго определено. Ей, в частности, запрещено переступать через очаг. Нарушение запрета считается тяжким грехом.

Мир труда кочевника в его социальном аспекте интерсубъективно типизирован и структурирован, представляет собой типизированный мир социального действия и коммуникации. Данный мир отличают типичные действия, типичные мотивы, типичные модели исполнения разных видов труда.

Однако тот труд, который исполняли кочевники тюрко-монголы отличается по своему смыслу от того, в котором его понимает А. Щюц. Этот труд не был активным изменением внешнего мира. Напротив, кочевники старались как можно меньше изменять окружающую их среду. Труд кочевника должен быть экологичным, так как в противном случае нанесение невосполнимого ущерба окружающей среде лишает его пастбищ и водных источников. Кочевники вынуждены следить за воспроизводством пастбищ, чистотой и сохранностью водных источников. К примеру, у монголов были табуированы стирка белья в водоемах - реках, озерах, ручьях, введен запрет на купание в них.

Восприятие внешнего мира у кочевника традиционного общества отличается от восприятия, живущего в десакрализированном мире, работника индустриальной эпохи. Также, как фабричный рабочий, кочевник не сомневался в существовании внешнего мира, считая, что мир таков, каким он воспринимается. Однако для кочевника явленный мир - это лишь зримая часть мира, который гораздо более разнообразен, глубок и опасен. Картина мира тюрко-монголов с древности до средневековья была синкретичной, в ее 
создании участвовали тэнгрианские, шаманские, буддийские религии. В разные периоды в евразийских степях, как пишет Ю. Дробышев доминировали те или иные религии, но чаще всего главенствовал Культ Неба. Тэнгрианство было естественным порождением образа жизни кочевников, к которому оно было наиболее адаптировано (Дробышев, 2014: 240).

Чувственное и сверхчувственное переплетены в опыте трудовой жизни кочевника. К примеру, если жертвенное животное, преподнесенное богам в буддийском обряде сетер, погибает, то стадо лишается защиты богов, а хозяин благополучия и удачи. Рассматривая экономические заповеди различных религий, исследователи отмечают, что поскольку отношения indigenous (коренных, аборигенных) людей с природой являются скорее взаимосвязью, чем инструментальными отношением, то использование ресурса ритуально оформляется. Прежде чем снять кору с кедра аборигены Аляски совершают обряд, прося прощения у духов дерева и обещают не брать больше, чем нужно. Такой подход создает осознанную и минималистскую этику использования ресурсов (Gardner, 2010: 29, Электр. ресурс).

Символизация трудовой культуры кочевников тюрко-монголов была чрезвычайно велика. Хозяйственные практики становятся опытом труда лишь будучи реализованы согласно тому символическому порядку, который был принят в том или ином кочевом сообществе. Хозяйственное освоение новых земель закреплялось всегда на символическом уровне. Так, с приходом в период раннего средневековья предков монголов в степи изменилась сакральная география, так как прежние тюркские маркеры - каменные бабы разбивались и опрокидывались. Устанавливались новые маркеры, указывающие на места силы - обо на горных вершинах и перевалах (Дробышев, 2006: 60-61).

Чтобы понять символизм трудовой жизни, нужно понять насколько важна символическая составляющая, символические и экспрессивные практики в культуре средневековых монголов, наследниками которых в той или иной мере считают себя современные тюрко-монголы. Ю.Дробышев предлагает любопытную интерпретацию военных жестокостей монголов. Чтобы понять, их следует рассматривать в контексте той символической реальности, в которой они жили. Уничтожение в иранском городе Нишапуре не только всех людей, но и животных (в 1221 г.) было, конечно, местью за смерть и пролитие крови члена дома Чингисхана (был убит зять хана), что расценивалось, как страшный грех. С этой точки зрения геноцид был действием экспрессивного порядка, устанавливающего достоинство и репутацию (Козлова, 1999: 26). Но, что гораздо важнее, этот геноцид символически превращал территорию Нишапура в «заповедник смерти», лишенный всякой потенции к жизни. Отрубив головы людям, размозжив кости им и животным, монголы, верящие в существование иной реальности, где после смерти эти существа могли бы жить, тем самым прекращали их загробное существование. Духи погибших после смерти 


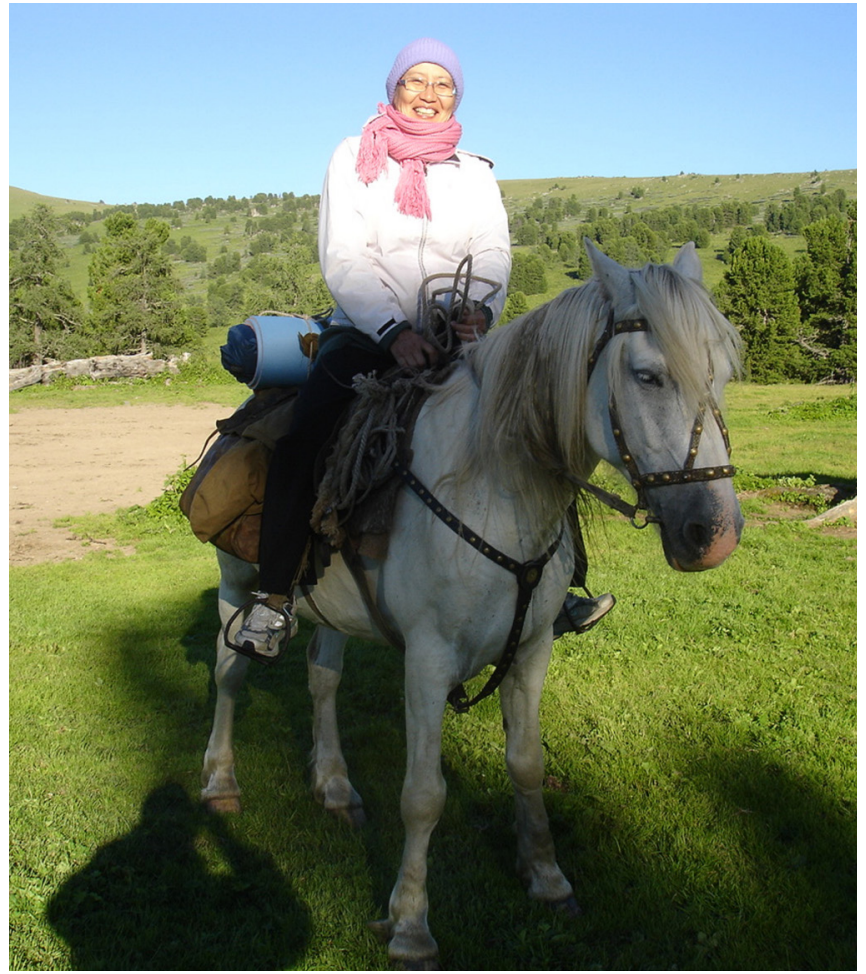

Фото 1. Автор в Усть-Коксинском районе Горного Алтая. Фото Р. А. Кушнерик, 20102. Photo 1. The author in Ust'-Koksinsky rayon of the Republic of Altai. Photo by R. A. Kushnerik, 2010.

лишались возможности оказывать покровительство живым. В созданном геноцидом анти-мире духи были бессильны (Дробышев, 2014: 457). Столбы из отрубленных голов создавались не только для устрашения, но символизировали расшатанную из-за гибели Чингизида мировую ось: «Гибель Чингисида ... открывала некую брешь, через которую врывались силы хаоса. Преградить им путь можно было, укрепив расшатанное мироздание посредством возведения “мировой оси”. Головы для этой цели подходили как нельзя лучше: они содержали в себе жизненную силу - сульдэ» (там же: 458-459).

Телесные практики тюрко-монголов насквозь пронизаны символикой. Формы коммуникации часто невербальны и основаны на оптико-кинетический способ передачи информации - жесты, мимика, знаковые ритуальные движения тела. Телесный язык составляют символические жесты приветствия, поощрения, указания, согласия, несогласия, презрения, угрозы и т. д. К невербальным способам коммуникации относятся также символика одежды, пространства, пищевой символизм (Бадмаева, 1992: 3-6).

Следовательно, выявление и изучение моделей труда, существовавших в культуре тюрко-монголов, возможно лишь с учетом символической составляющей трудового процесса.

\section{О типологическом единстве трудовой культуры тюрко-монголов}

Единство трудовой культуры тюрко-монголов обусловлено, во-первых, сходством символизма их культуры в целом, во-вторых, форматированием культур этих этносов в составе Великой Монгольской империи, в-третьих, схожим комплексом религиозных верований, среди которых важную роль, начиная с XVI в. начинает играть тибетский буддизм. Эти народы связывает единство тюрко-монгольского этногенеза в период монгольских завоеваний, а в дальнейшем - опыт пребывания в составе Российском империи. Решающую 
роль в форматировании тюркомонгольских этносов в социалистические нации сыграли преобразования советского периода, когда воплощался в жизнь проект советской модернизации.

Считается, что главным видом хозяйственной деятельности насельников евразийских степей было и является скотоводство. Скотоводство у племен, населявших евразийские степи в эпоху бронзы, развилось, проходя следующие этапы: придомное, пастушеское, яйлажное, кочевое. Появление кочевого хозяйства связано с появлением всад-

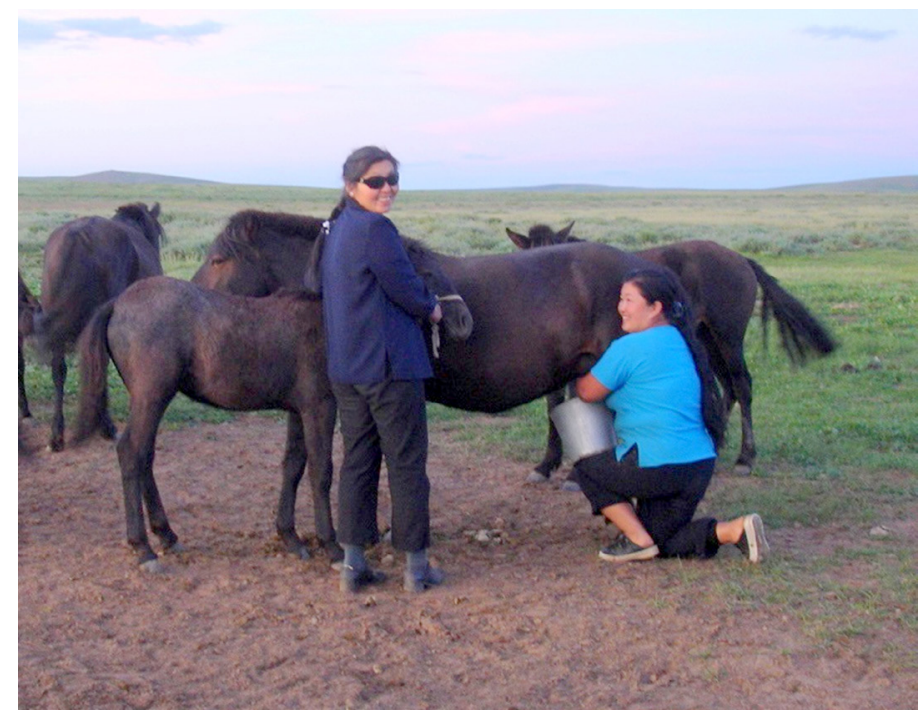

Фото 2. Доение кобылиц в кочевом хозяйстве Монголии. Фото Л. Четыровой, 2011 2.

Photo 2. Milking of mares at a nomadic farmstead in Mongolia. Photo by L. Chetyrova, 2011. ничества и колесничества, что придало насельникам евразийских степей исключительную мобильность. Коневодство, даже несмотря на численное преобладание овцеводства, стало доминирующим в хозяйственной, а затем символической системе (Жанисов, 2002: 88-89). Соответственно, появилась культовая практика и символическая составляющая. Этим объясняется появление культа коня и воспевание коня в эпосе и фольклоре тюрко-монголов.

Однако репертуар моделей труда, реализуемых тюрко-монголами с раннего средневековья, не ограничивался лишь скотоводством. Без труда ратного нормальное функционирование скотоводческого кочевого хозяйства было попросту невозможно. Для содержания скота на подножном корму требовались пастбища, борьба за которые шла между кочевниками непрерывно. Главными причинами миграций кочевников и одними из главных причин вооруженных столкновений между ними были захват и охрана пастбищ. Кочевники тюрко-монголы были всегда вооружены и при необходимости становились иррегулярными войсками, а в некоторых случаях, как, например, в империи Чингис-хана или Джунгарском ханстве - профессиональной армией.

Следовательно, главный вид трудовой деятельности кочевников тюркомонголов - скотоводство, то есть разведение овец, лошадей, крупного рогатого скота, верблюдов, тесным образом связано с ратным делом. Такая связь проявлялась, например, в институте скотокрадства (бур. - баримта, калм. - баранта), существовавшем у всех кочевников. Баримта (баранта) была актом восстановительной юстиции и осуществлялась либо по постановлению судебных органов, либо как личная месть. Такая кража скота у калмыков не считалась воровством, а, напротив, доблестью. Удальцы, участвовавшие в этом, 
восстанавливали таким способом справедливость. Баримта (баранта) могла быть возмещением ущерба, понесенного в ходе военных столкновений, разбоя или иных криминальных действий.

K примеру, людей калмыцкой владелицы Джал (XVIII в.), готовившейся к паломничеству в Тибет, и пославшей их в Царицын за необходимыми вещами, ограбили. Возмущенная владелица пишет астраханским властям, что возьмет баримту с купцов и просит власти не придираться к этому случаю (Сусеева, 2003: 60). Калмыки не рассматривали баримту (баранту) как воровство. Институт баримты (баранты) в трансформированном виде сохранился до настоящего времени. В Туве, например, кайгалы в 1990-е годы стали преступной субкультурой (Даргын-оол, 2006: 52-53).

С ратным делом связан также другой вид хозяйственной деятельности тюркомонголов - охота. На существование охотного промысла и наличие большого количества соболиных мехов у ранних монголов (шивэй) указывают китайские источники (Дробышев, 2006: 55). Соболиный мех использовался ими не только для ношения, но и в меновой торговле, и по стоимости был сопоставим со столь ценимым ими железом (там же: 57 ).

Как пишет Дж. Лэйн, облавная охота (nerge) у кочевников Евразии была частью их жизни и культуры. Персидский средневековый историк Джувейни писал, что Чингис-хан стал использовать облавную охоту как военные учения. Облавная охота была отличной тренировкой для войны и сражений. Такая охота, в которой принимал участие каждый воин и большая часть рода, начиналась осенью, длилась три месяца. Оттачивались такие воинские качества, как дисциплинированность, скоординированность действий, установление эффективных коммуникаций между подразделениями (тумэнами) (Lane, 2006: 107). Об этом же пишет Ю. Дробышев, ссылаясь на Великую Ясу Чингис-хана, сочинение Джувейни, а также работы Б. Я. Владимирцова. Охота играла в монгольском обществе особую роль, которая не сводилась к добыванию мяса или к развлечению. Чингис-хану приписывают такие слова: «Когда нет войны с врагами, пусть предаются делу лова - учат сыновей, как гнать диких животных, чтобы они навыкали к бою и обретали силу и выносливость и затем бросались на врага, как на диких животных, не щадя [себя]» (цит. по: Дробышев, 2014: 439). Охота сплачивала представителей разных родов и этнических групп.

Военное искусство монголов, несомненно, выросло из навыков ведения больших облавных охот, так как монголы использовали в военных операциях те же приемы, что и на охоте (там же). По словам французского историка Р. Груссе, монголы применяли приемы ведения охоты в своих атаках - маневры проводились молча, по сигналам флажков. Затем внезапно, в подходящий момент, атаковали с пронзительными криками, что сбивало противника с толку. Сражение было подобно охоте, монгол охотился человека точно также, как на антилопу или тигра. Самые известные кампании монголов в Трансоксиане, 
и в Венгрии выглядели как облавные охоты, в которых противника доводили до утомления, сбивали с толку, постепенно сужая круг окружали противника плотным кольцом и методично уничтожали его (Grousset, 1970: 224-225).

Последняя облавная охота у калмыков была проведена зимой 1757-1758 гг., когда наместник Дондук-Даши собрал на Куме около 2 тысяч человек, которые должны участвовать с его сыном Убаши в облавной охоте. Астраханский губернатор Жилин с тревогой увидел в таком скоплении калмыков войско, готовящееся выступить военным походом на Кабарду (Батмаев, 1993: 131).

С принятием монголами буддизма отношение к охоте изменилось. Принявшие духовные сан отказывались от охоты, а вокруг монастырей существовал заповедный режим земель. Запрет на охоту вблизи монастырей был законодательно закреплен на съезде монгольских князей в 1709 г. В период социализма, когда монастыри были закрыты, произошло сокращение численности основных промысловых видов - тарбагана, сайги, кулана и других копытных. Сегодня, по предварительным оценкам, охотой промышляет около 250 тысяч жителей Монголии, а их доход от охоты превышает 100 млн. долларов в год. Основной рынок сбыта - Китай (Дробышев, Гунин, Бажа, 2008: 122-123).

Итак, военные занятия средневековых монголов тесно переплетались и с таким видом хозяйственной деятельности, как охота.

Другим видом хозяйственной деятельности, издавна существовавшим у тюрко-монголов, было земледелие. В IX-XII вв. у населявших территорию Тувы, Горного Алтая и Северо-Западной Монголии тюрок существовало развитое земледелие, чему подтверждением служат значительное число древних оросительных каналов, сеть которых особенно выросла после IX в. Каналы имели каменные опорные стены. В Туве найдены древнехакасские косы-горбуши, втульчатые лемехи от плугов, что свидетельствует в пользу земледельческой традиции, существовавшей и у автохтонов Алтая и Тувы на протяжении веков (Кызласов, 1984: 108). Особенно земледелие было развито у древних хакасов, которые выделялись благодаря этому из других народов Центральной Азии и Сибири. Об этом свидетельствуют как письменные, так и археологические источники. Древнехакасский хлеб был действительно желанной и важнейшей добычей для многих степняков, как в ранние, так и в более поздние эпохи (там же: 103).

Впрочем, отношение тюрок к земледелию было неоднозначным. Тюркский Бильге-каган в VIII в. «берет также на вооружение и доводы против оседлого образа жизни, занятий земледелием в долинах. Он заклинает сохранить жизнь кочевников и скотоводов и постоянно иметь центром перемещений горную зону священных лесов» (Базен, 1986: 355).

Вопрос о существовании земледелия у монголов не прост. Как отмечает Ю.И. Дробышев, средневековые монголы, настоящие кочевники по своему 


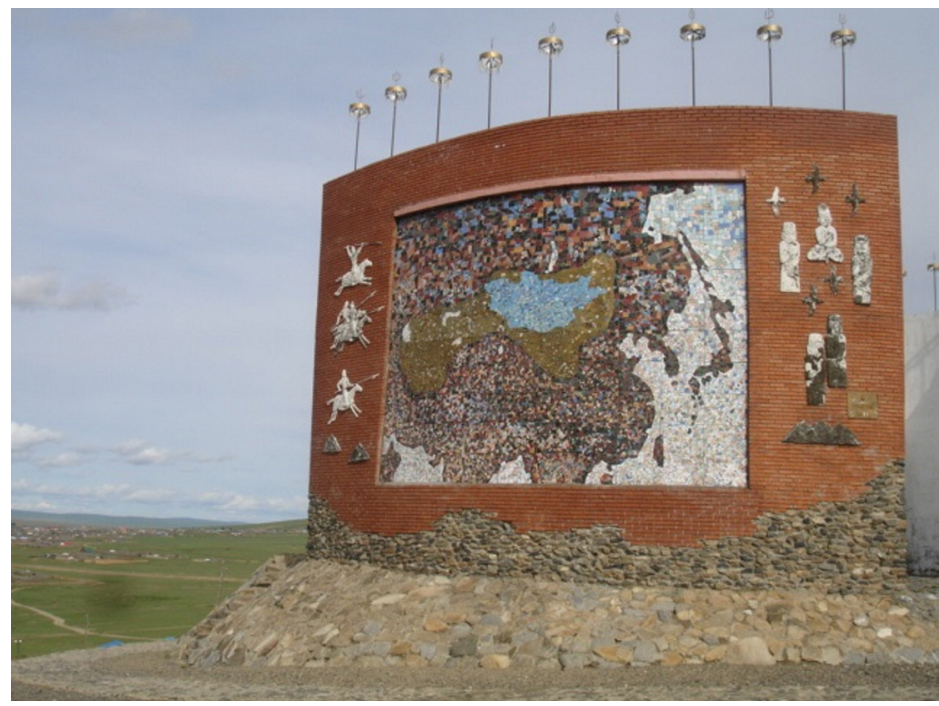

Фото 3. Мемориал в честь трех великих империй. Монголия. Фото Л. Четыровой, 20112.

Photo 3. Memorial in honor of Three Great Empires, Mongolia. Photo by L. Chetyrova, 2011.

преимущественно оседлый образ жизни.

Но даже кочевники практиковали земледелие. Оно, правда, осуществлялось весьма примитивным способом - клочки земли засевались весной и оставлялись до конца лета, пока хозяева кочевали в степях. Вернувшись, кочевники собирали урожай. Земля должна была быть достаточно плодородной и увлаженной - в долинах рек и подгорных шлейфах на краю степи (Дробышев, 2006: 55).

Е. И. Кычанов также приводит сведения в пользу существования земледелия у ранних монголов из династийной истории Тан «Цзю Тан шу». Здесь говорится о том, что эти племена «объединяются в группы и живут, иногда числом до нескольких десятков или сотен семей. Заостряют деревья и делают сохи, не насаживая на них металлических сошников (лезвий). Соху тянет человек, и производится посев. Не разрешается использовать (для пахоты) быков. Летом там много туманов и дождей, зимой много инея и снега. В качестве домашних животных там годятся собаки и свиньи» (Кычанов, 1980: 137). В источнике указано на влажный климат, описаны орудия труда.

Земледелие возможно, там, где количество годовых осадков составляет не менее 400 мм и есть реки (Масанов, 1995: 41). Ссылаясь на работы исследователей кочевой экономики, Н. Н. Крадин и Т. Д. Скрынникова пишут, что у монголов имелись такие условия, хотя и на ограниченных территориях, а значит было земледелие. Подтверждение тому они находят в «Сокровенном сказании», где есть упоминания о просе, ступах и хлебных запасах у меркитов (Крадин, Скрынникова, 2006: 77). Земледелие развивалось в долине реки Орхон, где располагалась столица Монгольской империи - Каракорум, один из районов 
которого - Карабалгас - был заселен земледельцами (Ткачев, 1987: 227-228). По словам В. Н. Ткачева, места в просторной долине хватало и земледельцам, и куреням воинов, и стадам скота. Однако, поскольку земледелие и скотоводство взаимоисключают друг друга по способу использования земель, то пашни и сады обносились стенами, представлявшими собой невысокие валы с плетневым забором. Они защищали поселения ремесленников и земледельцев (Ткачев, 1986: 228).

Исследователи отмечают, что создание кочевых империй стимулировало земледелие. На Керулене Чжан Дэ Хой в 1240-х гг. наблюдал возделывание земли монголами и китайцами вместе. Там сеяли только коноплю и пшеницу. В долине Орхона близ монгольской столицы он отметил орошаемые поля и огороды. Следы древней распашки сохранились в некоторых районах Монголии и Тувы (Дробышев, 2014: 435-436).

Нельзя не согласиться с Ю.Дробышевым, предостерегающим против упрощенного деления монгольских племен на «лесные», занимавшиеся в основном охотой и рыболовством и «степные», занимавшиеся скотоводством. Хозяйственный уклад «лесных» людей был неоднороден, здесь были охотничьерыболовецкие племена и скотоводческо-земледельческие (там же: 58).

В репертуар моделей труда помимо скотоводства, ратного дела, охоты и земледелия входит также ремесло, которое также было тесно связано с ратным делом - изготовление оружия, военного снаряжения, доспехов. В столице Монгольской империи Каракоруме существовал металлургически-керамический район, расположенный близ городища Тахай-балгас (Ткачев, 1986: 228).

С торговлей обстояло сложнее. Не будучи сами торговцами, кочевники применяли стратегию принуждения к торговле.

И, наконец, в репертуар трудовых моделей входил труд священнослужителей - жрецов тэнгрианского культа, шаманов, буддийских монахов. Все они исполняли возложенные на них функции профессионально - обладали необходимыми знаниями, которые получали либо в устной передаче, как шаманы и жрецы, либо учились в монастырях, как тибетские монахи. За свои услуги они получали плату, которая составляли либо их личный доход, либо доход монастыря. Кроме того, буддийские монастыри были крупными землевладельцами и владельцами скота, т. е. участвовали в хозяйственной деятельности (Дробышев, Гунин, Бажа, 2008: 126).

\section{Ключевые моменты развития трудовой культуры}

Ключевые моменты в развитии трудовой культуры я выделяю на основании этапов формирования тюрко-монгольских этносов и их трансформации в социалистические нации: 
- период существования Монгольской империи;

- постимперский период, характеризующийся многообразием тюрко-монгольских государств и, соответственно, этносов;

- период вхождения тюрко-монголов в состав Российской империи, проводившей политику христианизации и связанной с ней седиментации (оседлость и земледелие);

- советский период и формовка социалистических наций;

- постсоветский период.

Предки монголов, как уже говорилось, в VI-IX вв. жили в лесах, были оседлыми в прочных жилищах, занимались преимущественно охотой и рыболовством, выращиванием свиней и лошадей. В конце X - начале XI в. начался процесс постепенного расселения монголоязычных этнических групп, которые вытесняли и ассимилировали тюркоязычные групп. Всего за 200 лет они из лесных рыболовов, охотников и земледельцев стали всадниками - скотоводами. У тюрок они заимствовали породы степного скота, навыки и умения ухода за ним, а также передвижные жилища и другие формы материальной культуры степняков (Кызласов, 1984: 81).

Современем они стали «людьми на коне», своего рода кочевой аристократией, презиравшей земледелие, в котором, тем не менее, они нуждались. В период завоеваний они нашли выход в том, что земледелием принудили заниматься пленных и рабов, т. е. людей низкого социального статуса. Как отмечает В.Н. Ткачев, «зажиточные скотоводы, особенно аристократы, стремились в любой форме подчеркнуть свой социальный статус «человека на коне» (Ткачев, 1986: 221).

Переселение предков монголов в степи в настоящее время вряд ли может подвергаться сомнению. Можно спорить о частностях - месте расселения древних монголов, путях их миграции на запад, времени и сроках переселения, но лишь признанием факта миграции можно объяснить, как территория Монголии - исконная вотчина тюрок, стала местом формирования монголов как этноса-завоевателя (Кычанов, 1980: 148). Ойраты - лесной народ, предки современных калмыков до переселения на запад занимались охотой и вели полукочевой образ жизни. Став союзниками Чингис-хана и его подданными, они стали исполнять свой ратный долг и, соответственно, перешли к кочевому образу жизни монголов.

Изменение типа хозяйствования произошло в X-XI вв., когда монгольские племена мигрировали в степи современной Монголии. Из охотников, скотоводов с примитивным земледелием они превратились в кочевниковскотоводов (Кычанов, 1980: 144). Противоречивое отношение монголов к воде с одной стороны, боязнь загрязнить воду, с другой - крайне расточительное отношение к воде, отличающее их от жителей оазисов, исследователи объясняют 
происхождением монголов из богатых водными ресурсами мест (Дробышев, 2006: 59).

Используя данные своих наук, археолог Б. Дашибалов и лингвист В. Рассадин в своей совместной работе обосновывают, что предки монголов жили на территориях, прилегающих к морю, занимались рыболовством и земледелием. В. Рассадин обратил внимание на то, что большая часть монгольских слов, обозначающих степной ландшафт и степных животных, заимствована у тюрок (Дашибалов, Рассадин, 2004: 85). У бурят развита морская мифология, в которой представлены 27 морских божеств. У калмыков, бурят и монголов есть слова, обозначающие морских рыб, трепангов, рыбьего жира и т. д. (там же: 38). Привлекая к анализу описание земли из фольклорных произведений монгольских народов, авторы заключают, что древние монголы жили там, где были горы, перевалы, степи, песчаные места, соприкасающиеся с морем. Сегодня это современные провинции КНР Хэбэй, Ляонин и прилегающие территории Внутренней Монголии (там же: 40). Археологические находки - остатки домов, в фундаменте которых найдены черепа свиней, выполняющих защитную функцию, древних оросительных систем в Баргузине, говорят о том, что предки монголов вели оседлый образ жизни (там же: 36). Ю. И. Дробышев пишет, что «по мере продвижения в Халху и освоения кочевого образа жизни, в основу рациона монголы положили мясные и молочные продукты. Позже, видимо, не без влияния тибетского буддизма, доля рыбных блюд сошла практически к нулю» (Дробышев, 2006: 39). Об этом же пишет археолог Л. Р. Кызласов: ранние монголы были лесными рыболовами и охотниками, содержали придомно свиней, лошадей и не знали кочевого скотоводства (Кызласов, 1975: 172).

Такой важный вид хозяйственной деятельности, как торговля у тюркомонголов также связана с ратным делом. Кочевники издавна стремились выйти на рынки Китая, который долгое время отказывал им в этом. Как пишет Е. Баринова, в курганах кочевников Семиречья обнаружено всего несколько китайских монет. Однако, это не значит, что кочевники не торговали с Китаем. Правильней будет предположить, что основной формой торговли был обмен, а не купля-продажа. Данная форма торговли вытекала из дани и обмена подарками (Баринова, 2013: 248).

Если оценить завоевания Чингис-хана с этой точки зрения - установления торговых отношений, то ясно видно, что целью великого хана был не столько захват богатств завоеванных государств или обложение покоренных народов данью, сколько установление контроля над Шелковым путем. Шелковый путь издавна связывал три великие цивилизации - Китай, Индию и Средиземноморье. Беря начало в Сиане (Чанъань, Китай), он разветвлялся на множество путей, ведущих в города Индии и Средиземноморья. Монголы, которых отделяли от этого торгового пути всего пятьсот километров, покупали у торговцев предметы роскоши - шелк, шерстяные ткани, серебряную посуду, 
способную, как они считали защитить от яда и черной магии, оружие, жемчуг, полудрагоценные камни, музыкальные инструменты, раковины, лекарства и косметику для богатых женщин. Взамен они, правда, мало что могли предложить. Торговцев интересовали не грубой выделки кожи кочевников или иные продукты скотоводства, а соболиные меха, шкуры антилоп, тигров, волков, рога лосей, северных оленей. Китайская медицина широко использует разные части тела диких животных - от языка до хвостов и тестикул (Weatherford, 2010: 46-48).

Большую часть этих привлекательных с точки зрения продажи предметов можно было найти у ойрат, проживавших в лесах на северо-западе озера Байкал. Как полагают западные исследователи, Чингис-хан, строя свою империю ставил целью установить контроль над торговыми путями, главным из которых был в то время Шелковый путь. Великий хан использовал не только военные средства, но и брачные стратегии. Для реализации своей цели он выдал свою дочь и внучку за двух сыновей ойратского правителя. А ойраты в то время проживали в лесистых землях, богатых пушным зверем. В брачном указе Чечеген было сказано, что будучи дочерью своего отца - хана, она послана править ойратами. В то время как ее муж Торолчи был отозван к войскам Чингис-хана для того, чтобы сражаться в армии. Благодаря статусу Чечеген ойраты получили контроль над северными торговыми путями (Соболиный путь) (там же: 46-48).

Брак другой его дочери Алагай-беки позволил ему установить контроль уже собственно над Шелковым путем. Северные подходы к Великой стене со стороны Монголии, в северной части провинции Шаньси, охраняли тюрки-федераты, онгуты, исповедовавшие несторианское христианство.Обидевшись на китайцев, онгутский вождь Алакуч-тегин в 1204 г. перешел на сторону Чингис-хана. Для укрепления союза с домом Алакуча хан отдал одну из своих дочерей за его племянника (Рахманалиев, 2009). В брачном указе он говорит, что она должна стать «одной из его ступней» (one of my feet), «быть его помощницей в походах» (там же: 53-54). Ее муж, также как другой зять великого Хана, был послан воевать, а она стала единоличной правительницей народа, контролировавшего Великую Китайскую стену и эту часть Шелкового пути.

В конечном итоге Чингис-хан установил контроль над самым главным торговым путем Евразии. Великая империя, в которую вошли народы разных культур, верований, экономических и технологических достижений, была пространством первых глобализиционных процессов. В рассматриваемом случае - созданием мировой торговли. Так Чингис-хан при помощи браков своих дочерей создавал предпосылки для мирового торгового сообщества.

Что касается населения империи, то, как пишет Мак-Нил, знания о цивилизованной жизни все сильнее проникали в среду степных кочевников. Более тесные контакты с крестьянами и горожанами были всегда выгодны для них - крупы, ткани, металлы и украшения были ценными дополнениями 52 
к тем достаточно скудным продуктам, которые кочевники получали от животноводства и охоты. Поэтому по мере усиления этих контактов в результате торговли и службы наемниками в армиях цивилизованных государств жители степей получали более обширные знания о богатстве и чудесах цивилизованных стран, и соответственно усиливалось влияние Китая, стран Среднего Востока и Византии на наводящих ужас степных воинов» (Мак-Нил, 2004: 152).

Таким образом, форматирование тюрко-монголов в пространстве империи Чингис-хана способствовало созданию модели хозяйственного труда, тесно связанного с исполнением ратного дела.

Входя впоследствии в состав Российской империи, тюрко-монголы подверглись иному форматированию. В ходе создания новой империи менялись не только символы, существующие у русских, но символы нерусских, вовлекаемых в ее орбиту. Если у русских происходил разрыв с традиционной допетровской культурой, то у них - с собственной традиционной культурой. В ходе такого разрыва и аккультурации, осуществляемой разными способами - от сегрегации до интеграции, осуществлялось формирование новой идентичности нерусских подданных империи. Идентичность в данном случае выстраивалась согласно их пониманию власти, правителя, родины, подданного. Смысл каждого из этих явлений менялся по мере вхождения нерусских в политическое пространство империи и, соответственно, менялись символы их выражающие. Империя формировала идентичность своих подданных, используя православие. Не столько важна была этническая, сколько религиозная идентичность. Этим объясняется недоверие российских властей к тибетскому буддизму, как к религии иностранного происхождения. Недоверие к буддизму усиливалось изза того также, что калмыцкие ханы прибегали для легитимации своей ханской власти к далай-ламе, тибетскому иерарху, проживавшему в другом государстве.

у тюрко-монголов пастбищное скотоводство по-прежнему оставалось главным видом хозяйственной деятельности. Однако его тесная связь с ратным делом была разорвана в результате вхождения в Российскую империю. Ратное дело исполнялось как самостоятельный вид деятельности, который калмыки, например, исполняли как условие их вхождения в Российскую империю.

Христианизация кочевников предполагала перевод кочевников к оседлому образу жизни путем приобщения их к земледелию. Данная стратегия была основной в отношениях с кочевниками вплоть до Великой революции 1917 г. Однако, большого успеха имперская власть в этом вопросе не достигла.

У калмыков с конца XVIII в. складываются три главные хозяйственнокультурные группы: кочевники-скотоводы, обитающие в центральной части Калмыкии; обитатели западной, возвышенной части Калмыкии с плодородными землями, сочетающие скотоводство с земледелием; жители низовьев Волги и Каспийского взморья сочетали скотоводство с рыболовством (Бадмаев, 2007: 10). 


\section{Рождение субъекта или опыт труда в советской модернизациии}

Победа большевиков на территориях бывшей Российской империи, а также на территории Монголии и установление советской власти для населения этих территорий имели беспрецедентные следствия - возникли новые нации, резко выросла грамотность населения, были созданы абсолютно новые формы хозяйственной деятельности, появились новые социальные институты. Проект советского модернизации, успешно реализованный большевиками, был нацелен на радикальное переустройство оснований общества на рациональных принципах. Будучи обществами модерна, и социализм, и капитализм требуют десакрализации всех сторон социальной жизни. Политическая победа в революции и последовавшей за ней гражданской войне стала началом новой революции, которая разворачивалась в символическом пространстве по разным направлениям. Если брать труд тюрко-монголов, то необходимо было вычленить его из той символической структуры, в которую он был вписан и вне которой он не только не осуществлялся, но и не мыслился.

Это было сделано достаточно быстро благодаря, во-первых, переводу кочевников на оседлый образ жизни и приобщению к земледелию, во-вторых, агрессивной антирелигиозной кампании, завершившейся ликвидацией, в том числе физической, священнослужителей, уничтожением религиозных институтов и учреждений. Символы старой культуры сменялись новыми социалистическими. Осуществляя культурную революцию, большевики создали чрезвычайно эффективную машину по производству символов, репрезентирующих общество нового типа, в котором труд должен был стать смысловым центром. Важную роль в утверждении его в этом качестве сыграл А. М. Горький (Доренко, 2007: 237). Как полагает Е. Доренко, искусство социалистического реализма - литература, кино, фото, продуцируя образы социалистического производства, а также образы товаров, тем самым создавало символические предметы потребления советских граждан: «Социалистическое хозяйство растет не от потребления товаров, но от потребления самого производства в виде его образа и образов товаров. В процесс потребления этого символического производства и производится “социализм”. Символическим продуктом социализма является само производство (“труд”); символическим этого производства является “изобилие” (“культурна зажиточная жизнь”, созданная в соцреализме)» (там же: 405). Однако вряд ли можно согласиться с его утверждением, что «социалистическое производство занято почти исключительно воспроизводством собственного образа» (там же). Социалистическое производство все же производило реальные предметы.

Проект советской модернизации воплощался в жизнь планомерно, эффективно и дал положительные результаты. Калмыцкая земля, долгое время бывшая мечтой безземельных русских крестьян, стала в объектом 
рационального землеустройства. Как пишет Е. Н. Бадмаева, была создана Поволжская колонизационно-мелиоративная экспедиция (ПКМЭ), в задачу которой входило плановое переселение крестьян на пустующие земли Поволжья - Самарскую, Саратовскую, Сталинградскую, Астраханскую губернии и Калмыцкую область (1924-1926). Экспедиция пришла к выводу, что несмотря на пригодность к земледелию лишь одного Большедербетовского района и небольшой части Донского треугольника, занятия земледелием, садоводством и огородничеством будут способствовать приобщению калмыков не только к новым видам хозяйственной деятельности и продуктам питания, но и изменению самого уклада жизни калмыков Экспедиция занималась мелиоративными, пескоустроительными и землеустроительными работами. Было обеспечено водой более 14 тысяч хозяйств (Бадмаева, 2009: 91-92). Поделив Калмыкию на четыре части: земледельческо-скотоводческую, скотоводческо-земледельческую, скотоводческую и рыболовно-скотоводческую, ПКМЭ рекомендовала активнее развивать рыбную промышленность (там же: 92). Строительство нового общества в Калмыкии осуществлялось согласно этим установкам. Поскольку в результате революции и гражданской войны калмыки потеряли большую часть скота, то единственным способом выживания стал переход к оседлому образу жизни, связанному с этим земледелию и рыболовству.

Отношение кочевников к земледелию хорошо иллюстрирует пример с монголами, родственными калмыкам по традиционной трудовой культуре. Когда после революции 1911 г. китайцы, среди которых были не только торговцы, но и земледельцы, выращивавшие зерновые культуры, были изгнаны, власти столкнулись с нехваткой хлеба. Монгольским правительством был издан указ, согласно которому кочевники должны выращивать зерновые. Реакция аратов была однозначно негативной. Главный аргумент - распашка земли потревожит духов-покровителей гор и вод, и «они могут наслать разные болезни и несчастья на людей и животных» (Шубин, 1953: 78).

Тем не менее, сопротивление аратов переходу к земледелию было преодолено и к 1985 г. в социалистической Монголии обрабатывалось 1253 тыс. га. Исследователи считают, что несмотря на восстановление религиозных институтов и оживление религиозной жизни, отказ от земледелия по религиозным убеждениям вряд ли возможен (Дробышев, Гунин, Бажа, 2008: 134).

Народный комиссариат труда в 1920-е годы разработал систему мероприятий для интеграции в сферу производственного труда национальных меньшинств: подготовка квалифицированной рабочей силы из числа «националов», особый контроль за их трудом со стороны инспекции в целях предотвращения эксплуатации и нарушений трудового законодательства; выявление предприятий, куда отправлять их в первую очередь (Франке, 2008: 157-158). В результате успешной реализации советской модернизации в большинстве регионов проживания российских центрально-азиатских этносов сформировалась модель 
труда оседло живущего работника, исполняющего и производительные сельскохозяйственный, индустриальный и непроизводительные (образование, наука, медицина и т. д.) виды труда.

Традиционно кочевники стремились иметь в своем хозяйстве пять видов скота: лошадей, овец, коз, коров и верблюдов, стремясь избежать рисков специализации. Социалистический тип хозяйства, напротив, требовал узкой специализации в разведении скота (Дробышев, 2008: 127-128). Однако советская модель труда, сформировавшаяся в сельском хозяйстве, изначально была противоречива. И. Кознова указывает на противоречивость понятия «советский крестьянин» (Кознова, 1997: 361). Действительно, это понятие обозначает сельскохозяйственного работника, с одной стороны, трудящегося в коллективном хозяйстве за деньги, с другой - относительно автономного хозяйственного субъекта, занятого в своем личном подсобном хозяйстве (ЛПХ).

И, как верно подметила К. Хэмфри, жизнь советских тружеников села протекала в этих двух измерениях. К 1970-м годам система советского сельского труда достигла потолка иерархической бюрократизации и трудовой специализации. Люди привыкали считать себя трактористами, скотниками, механиками, получающими зарплату, а не крестьянами. К тому же ЛПХ приносило все меньше дохода и требовало больших усилий, поэтому легче и проще было купить продукты в магазине (Хэмфри, 2010: 177). Человек постепенно переставал чувствовать себя крестьянином, а в нашем случае скотоводом, связанным с природой. Кроме того, политика патернализма, реализуемая советским государством в социальной сфере, воспринималась жителями сел в этнических регионах, все еще сохранивших категории восприятия традиционной культуры, как забота старшего - государства о младшем. Этим объясняется неготовность большинства тувинцев быть автономными хозяйственными субъектами: «Младший член семьи ориентируется на старшего - государство, ждет и требует от него гарантий для своего существования» (Даргын-оол, 2006: 53).

Лишь немногие из сельских жителей сумели стать автономными хозяйственными субъектами в той экономической ситуации, в которой они оказали в результате аграрных реформ 1990-х годов.

Пастбищное скотоводство в советское время считалось отсталым и примитивным. Восстановление традиционных форм хозяйственной деятельности в крестьянских хозяйствах в какой-то мере вернуло ему прежний статус. Такой тип скотоводства наиболее пригоден для аридных земель, на которых проживают значительная часть тюрко-монголов. Плановое ведение сельского хозяйства в советских период, организация его на научных основах в области животноводства проявила себя как забота об улучшении породы скота. В итоге произошла метизация скота, когда породы местной селекции смешивались с завезенными. В результате изменился породный состав скота, который стал 
более требовательным к условиям содержания и кормления (Потаев, 2011: 71).

Современное пастбищное скотоводство в Калмыкии имеет две разновидности: пригонную, если пастбища находятся вблизи скотных дворов $(0,5-1$ км $)$ и отгонную, если пастбища удалены на 2 и более километров. Скот остается на отгоне в течение всего пастбищного периода. На летнике устраиваются навесы для ночлега скота, дойки, для размещения персонала. Такая система называется летнее лагерное содержание скота (Чимидов, 2009: 483). Способы

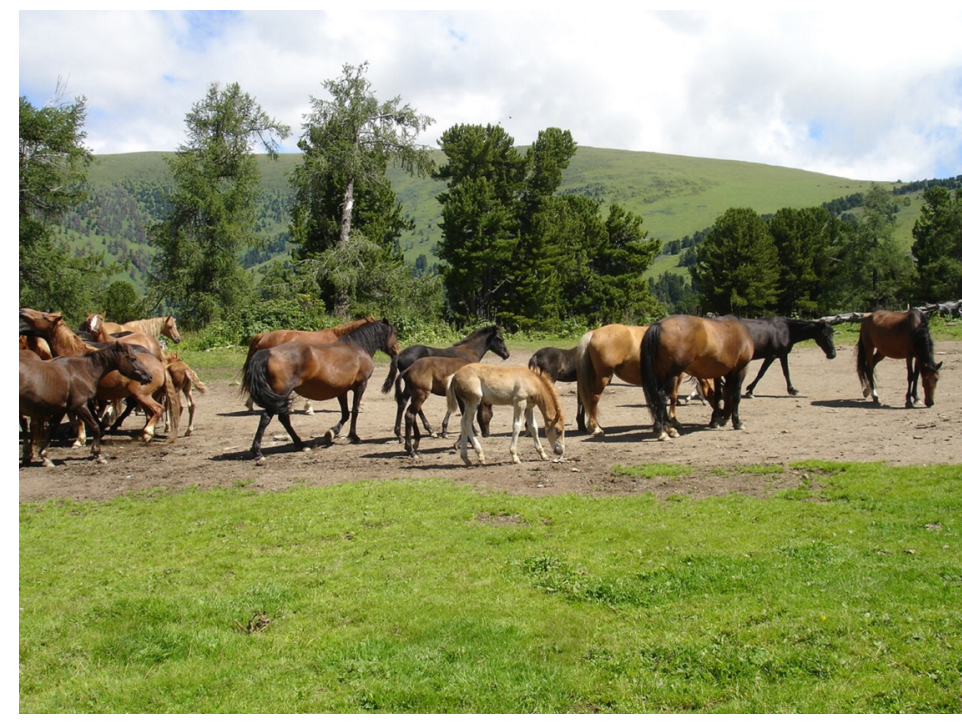

Фото 4. Косяк лошадей, принадлежащих сельским предпринимателям. Горный Алтай. Фото Л. Четыровой, 2010.

Photo 4. A herd of horses belonging to the rural entrepreneurs. Altai Mountains. Photo by L. Chetyrova, 2010. использования пастбищ различаются на вольный (бессистемный) и загонный (участково-загонный) выпас. Последний способ, требующий деления пастбища на участки для однодневного стравливания, был предложен еще в XVIII в. западноевропейскими специалистами (там же: 484).

\section{Фермеры и шаманы}

Экономический коллапс, в который оказалось ввергнуто постсоветского общество, запустил разные стратегии выживания, в числе которых было обращение к архаике в этнических регионах (Ламажаа, 2013). В трудовой сфере такими стратегиями стало не только возрождение пастбищного скотоводства, но институциализация и легализация шаманов, целителей (медлгчи, бё). Тюрко-монголы по-прежнему занимаются скотоводством, к чему их обязывает среда обитания. Монголоязычные народы, занимая 2,7\% территории России, составляют всего 1,7\% населения. Одним из показателей, характеризующих конкурентоспособность региона, является плотность населения. Невысокая плотность населения - следствие суровых природно-климатических условий. Этим объясняется, что этнические регионы в рейтинге субъектов Российской федерации занимают последние места (Атанов, 2010: 35-37).

Животноводством в этнических регионах сегодня в основном заняты крестьянские хозяйства и ЛПХ. Основной контингент сельских предпринимателей сельскохозяйственного типа в этнических регионах составляют 


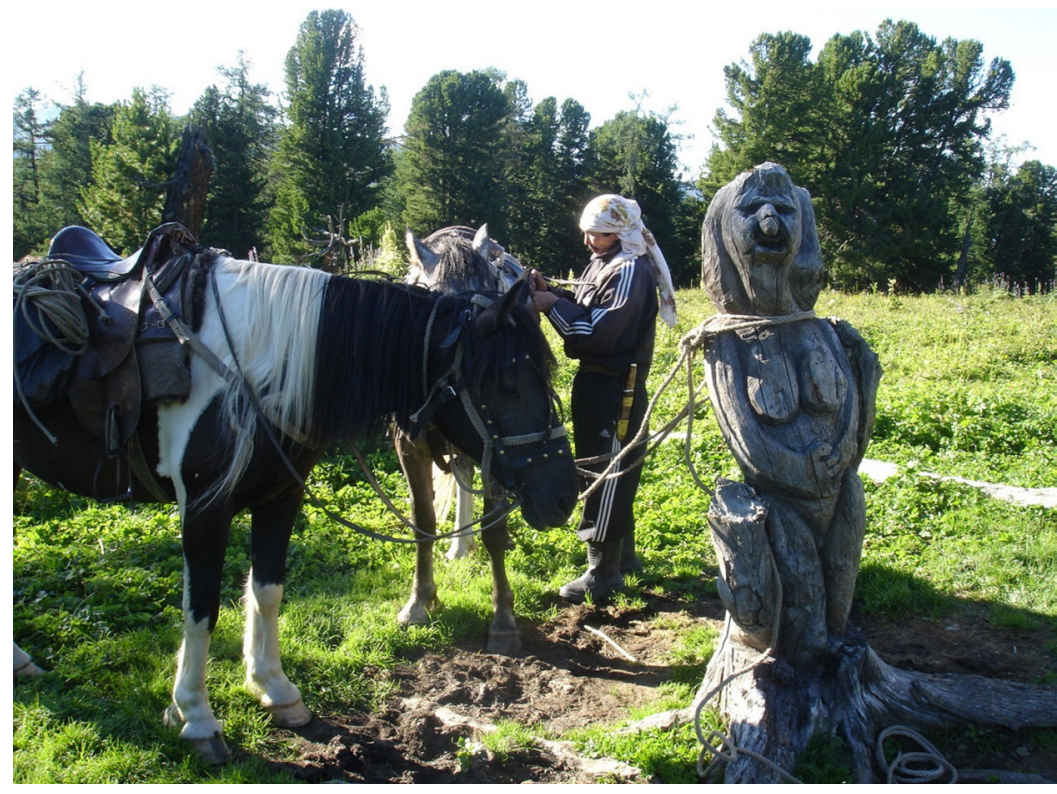

Фото 5. Фигура, вырезанная сельским предпринимателем, выполняющая функции оберега на летнике в горах. Горный Алтай. Фото Л. Четыровой, 2010 г.

Photo 5. A statue carved by a rural entrepreneur and performing the func-tions of an amulet for a nomadic household. Altai Mountains. Photo by L. Chetyrova, 2010.

семейные хозяйства. Они удалены от населенных пунктов и представляют собой, как правило, альянс род с тв ен ны х с е м й . Б. Нанзатов, обследовав закаменских бурят, живущих в гористой местности, составил типичную модель функционирования такого хозяйства. Родственные семьи дифференцированы по месту проживания часть живет в населенном пункте, обеспечивая доступ к школе детям, реализацию продуктов животноводства, ч а с т ь - н а фе р м е , занимаясь полудиким содержанием скота. Выбор породы скота обусловлен их рентабельностью. Закаменские фермеры предпочитают калмыцкую породу КРС, который относится к аборигенному типу скота, сформировавшемуся в аридных зонах Центральной Азии (Нанзатов, 2010: 74). Схожая картина наблюдается в Республике Горный Алтай, где занимаются разведением лошадей, применяя исконные способы ухода за ними. Косяки лошадей находятся в горах, на летниках.

Часто фермеры используют наемный труд односельчан, которых нанимают на заготовку кормов, окот или строительные работы (там же: 74). Работники, как правило, работают сезонно и относятся к категории прекариев современных рабов.

Помимо животноводства источником пополнения семейного бюджета у закаменских бурят является охота, сбор орехов и дикоросов. Охота ведется на пушные - соболь, белка, лиса, рысь, кабаргу, медведя. Большим спросом у китайцев, как и в стародавние времена пользуется медвежья желчь, струя кабарги, рога копытных (там же: 76-77).

В этнических районах России - Калмыкии, Бурятии, Туве, Горном Алтае доля незанятого населения выше, чем в среднем по России. Статус безработного, однако, не означает, что человек не участвует ни в каком виде трудовой деятельности. Часть из них составляют так называемое самозанятое население, 
доход которых на 20-25\% ниже, чем у сотрудников организаций - 20800 рублей (Деготькова, 2018: Электр. ресурс). В хозяйственной России сложился такой феномен, как современное отходничество (Отходники, 2013). Отходники из этнических регионов, особенно буряты и калмыки, ездят на заработки не только в Москву и СанктПетербург, но и за рубеж Южную Корею, США, Италию, Испанию и другие страны.

Результатом восстановления традиционной формы хозяйствования в форме крестьянского скотоводческого

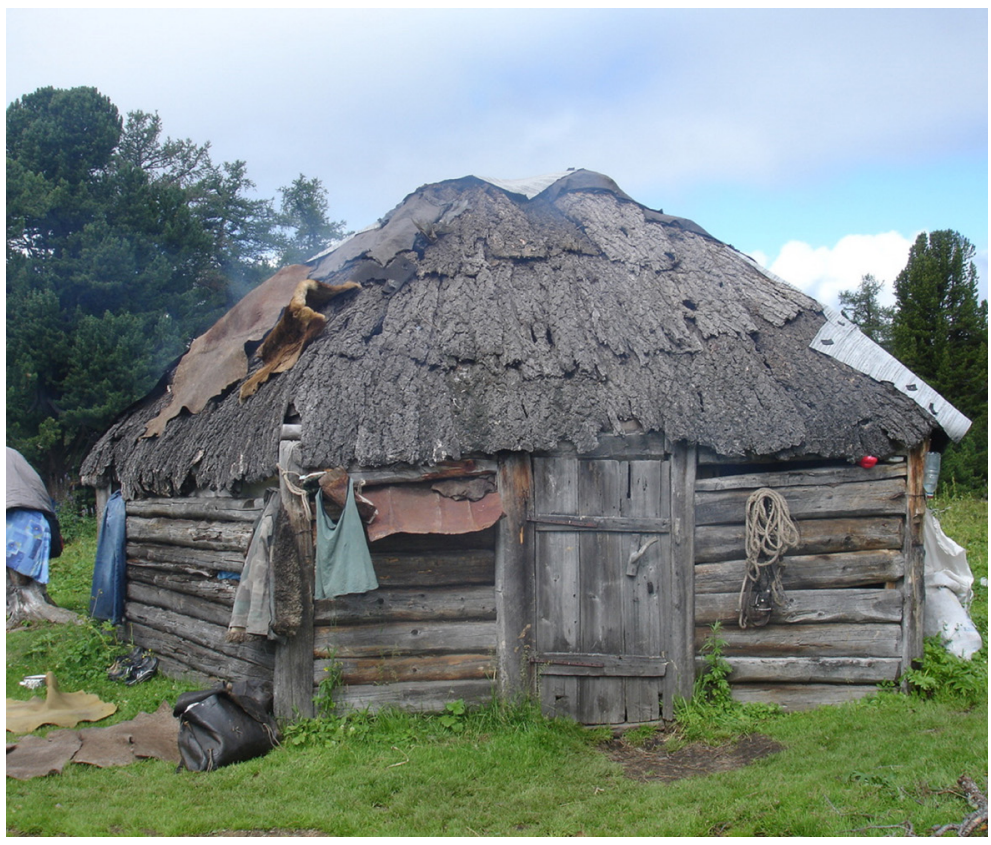

Фото 6. Аил на летнике в горах. Горный Алтай. Фото Л. Четыровой, 2010 г.

Photo 6. Ail (an ethnic house) in the mountains. Altai Mountains. Photo by L. Chetyrova, 2010. хозяйства вкупе с восстановлением религиозных институтов, в частности института шаманов, стала неоархаическая модель труда. Труд, как и в прежние времена до советской модернизации, интегрирован в сложную символическую структуру. В случае закаменских бурят - это духи-покровители гор, вод. До настоящего времени занимающиеся отгонным скотоводством западные буряты строят на летниках деревянные юрты, выбор места для которых происходит согласно признакам - положительным или отрицательным, характеризующих место с символической точки зрения. Буряты никогда не буду возводить жилище на месте, которое было обжито и покинуто другими людьми. Считается, что духи-покровители прежних хозяев остаются на месте и духи-покровители, которыми обзаводятся новые хозяева, вступают в конфликт друг с другом. Обитателям вновь отстроенного жилища такой конфликт ничего хорошего не приносит (Содномпилова, 2002: 122-123).

Исследуя в 1960-1970-е годы бурят в Баянголе и Баргузине британская антрополог К. Хэмфри нашла, что буряты, идя на охоту, всегда делали подношения духам. Она пришла к выводу, что шаманские, буддийские ритуалы, смешавшись друг с другом, были связаны с советскими ритуалами (Humphrey, 1983: 373). Она показала, как социально-экономическая ситуация повлияла на такие важные ритуалы, как Сагаалган, знаменующий Новый год и Сурхарбан, проводимый в преддверии урожая. По ее мнению, первый праздник сохранил религиозное содержание, а второй, связанный в группами работников, стал 


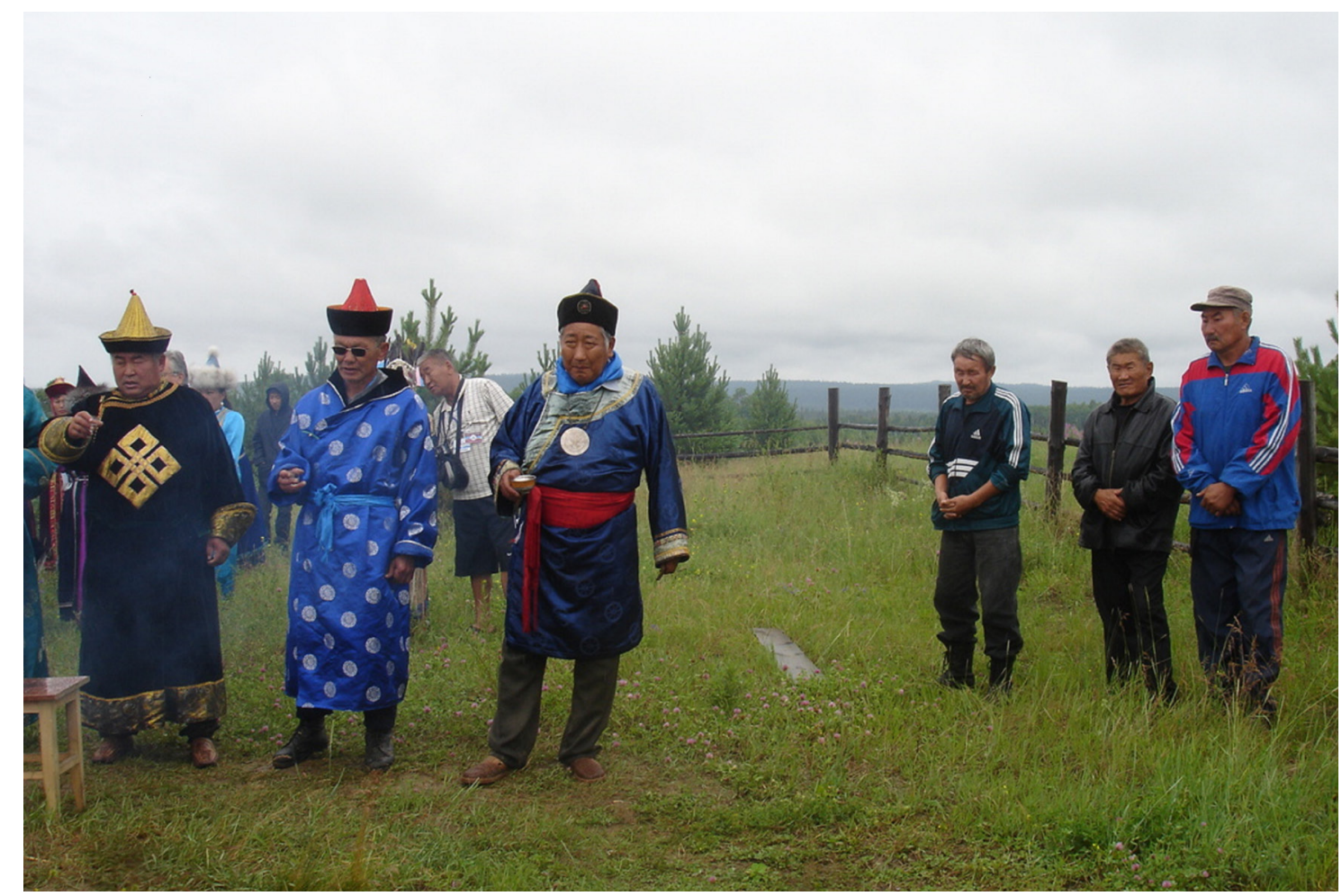

Фото 7. Ритуал подношения духам местности, исполненный шаманами для туристов. Бурятия, озеро Байкал. Фото Л. Четыровой, 2010 г.

Photo 7. The ritual of offering to the spirits of the land performed by shamans for tourists. Buryatia, Lake Baikal. Photo by L. Chetyrova, 2010.

секулярным (там же: 378). По мнению пожилых бурят, существует цикличность в смене ламаизма и шаманизма. Шаманизм был изгнан ламаистами, которых в свою очередь изгнали коммунисты. И вот сейчас настало время возвращения шаманизма. В прежнее время в каждой деревне было от одного до пяти шаманов (там же: 404). В советский период, несмотря на резкое сокращение их численности, они исполняли шаманские практики. Шаманы в Баргузине принимали в двух типах ритуалов: обоо тахилга - коллективное подношение духам местности и тайлган - подношение духам-покровителям рода. Ссылаясь на Т. Михайлова, она пишет, что лишь треть участников ритуала тайлган были «активно верующими» и понимали смысл ритуала (там же: 410).

В 1990-е годы с началом восстановления традиционных для России религий произошла легализация деятельности шаманов. Шаманы стали открыто осуществлять свою деятельность, которую следует квалифицировать как профессиональную. Для того, чтобы быть признанным в качестве шамана, необходимо иметь соответствующие эзотерические знания, обладать навыками и умениями, а также получить легитимацию со стороны шаманского сообщества. Поскольку они получают плату за свои услуги, то их деятельность является трудовой.

Восстановление шаманских традиций, во многом утраченных в советское время или слившихся с советскими ритуалами, стало возможным благодаря 
работам этнографов, которые в своих публикациях описывали полученные во время полевых исследований шаманские практики. Наиболее известными и авторитетными специалистами в этой области являются Т. М. Михайлов (1929-2009) и М. Б. Кенин-Лопсан. Последний - практикующий шаман. В ноябре 1992 г. он учреждает Религиозную организацию тувинских шаманов «Дунгур» («Бубен») (Общество шаманов, http://www.dungur.ru/). Годом позже при Республиканском краеведческом музее им. Алдан-Маадыр (60 богатырей) учреждается Научный центр по изучения шаманизма. В 1994 г. Фонд исследований шаманизма (Foundation for Shamanic studies, Mill Valley, CA, USA) присвоил М.Б. Кенин-Лопсану звание «Живое сокровище шаманизма». Шаманы вновь стали исполнять свои лечебные, предсказательные и иные функции. Тот факт, что они объединены в централизованную организацию, подтверждает их профессиональный статус. В Кызыле организация шаманов была коммерчески ориентированной, на табличках помещались надписи с указанием цен на услугу - изгнание демонов из дома, проводы умершего (Хэмфри, 2010: 372).

Перформативный и визуальный характер культуры общества потребления, частью которого являются представители этнических обществ, выражается в появлении различных центров шаманизма, реализующих перформативную практику. Шаманские представления исполняются не только для последователей шаманизма, но и для туристов, движимых в поисках новых развлечений мультипликацией желаний. K такому же типу относятся перформативные действия, реализуемые буддийскими священнослужителями (создание песочных мандал, танцы Цам и др.).

Восстановление буддийской традиции в тюрко-монгольских регионах шло по-разному. В Бурятии буддийская традиция сохранилась лучше, чем где бы то ни было в советское время. В остальных буддийских регионах, особенно в Калмыкии, восстановление традиции шло путем приглашения тибетских учителей, стремящихся к восстановлению аутентичной буддийской традиции.

Как показывают социологические исследования, благодаря восстановлению религиозных традиций шаманизма и буддизма заметно поменялись категории восприятия, в особенности у молодежи этнических регионов (Евразийский мир, 2010).

Для тружеников села - скотоводов, в частности, это означало восстановление прежней духовно-практической системы труда, где производственные усилия вписаны в сложную систему взаимодействия человека с реальностью иного, влияющей и определяющей ход его трудовой жизни.

Шаманы не только «вышли из подполья» в селах, но и появились в городах. Это новый феномен не только в шаманизме, но и в городской жизни. К. Хэмфри, исследуя город, как «рабочее место» шаманов, пишет, что самые известные шаманы Улан-Удэ выросли в городе, происходят из семей интеллигенции, среди них есть и мужчины, и женщины. Они входят в профессиональную ассоциацию 
и отделяют себя от всякого рода знахарей, экстрасенсов, ясновидящих, которых они считают шарлатанами (Хэмфри, 2010: 361-362).

По мнению К. Хэмфри, городских шаманов следует отнести к категории постмодернистских шаманов. Эти шаманы преобразуют городскую среду, восстанавливают связь городской территории с другими временами и пространствами, наполняя ее энергией, преобразуя социальные отношения в рамках города (там же: 362-363). Город, следовательно, вписывается в реальность, имеющую два уровня - профанный и сакральный.

Постмодернистские шаманы наряду с традиционными духами предков используют в качестве духов предыдущие воплощения клиентов, потаенные «я», которые скрываются в личности и портят жизнь (там же: 372). В городе шаман объясняет несчастья клиентов разрывом связи с духами предков, так как в 1990-е годы многие сельские буряты мигрировали в города. Практика городских шаманов, по мнению К. Хэмфри, не только помогает восстановить связи бывших сельчан с духами предков, но и «взрывает» буддийские и светские институции - школу, больницы, дацан, превращая городское пространство в «места силы».

\section{Заключение}

Подводя итоги, следует сказать, что в истории трудовой культуры бурят, калмыков, монголов, тувинцев конкурирующими были две основные модели труда: труд кочевника-скотовода и труд земледельца. Причем первый всегда был связан с ратным делом. Особенность этих моделей труда состоит в том, что они возникали и изменялись под форматирующим воздействием разных империй - монгольской, российской, советской империи наций. Кроме того, изучение моделей и образом труда тюрко-монголов предполагает выявление того символического контекста, в котором выявится их подлинный смысл и значение.

В репертуаре моделей труда тюрко-монголов важное место занимает труд тех, кто отвечает за связь труда с реальностью иного - сакральным миром духов или буддийских божеств. Поскольку подобные занятия требуют профессиональной подготовки: приобретения знаний, освоения навыков и умений, а также осуществляются за плату, то их следует квалифицировать как трудовую деятельность.

\section{СПИСОК ЛИТЕРАТУРЫ}

Атанов, Н. И. (2010) Трансформация хозяйственного уклада монголоязычных народов Южной Сибири // Глобализация и монгольский мир : сб. статей по материалам Международной научной конференции, проведенной 15-18 июля 
2010 г. (в рамках IV Заседания Генеральной сессии Конвента монголов мира в Улан-Удэ) / гл. ред. Б. В. Базаров. Улан-Удэ : б/и. 387 с. С. 35-39.

Бадмаев, В. Н. (2007) Кочевая культура как фактор хозяйственной жизни калмыцкого этноса // Вестник Калмыцкого регионального отделения Российского философского общества. № 1. С. 7-12.

Бадмаева, Е.Н. (2009) Поволжская колонизационно-мелиоративная экспедиция в Калмыкии периода НЭПа // Материалы Международной научной конференции «Единая Калмыкия в единой России: через века в будущее», посвященной 400-летию добровольного вхождения калмыцкого народа в состав российского государства (г. Элиста, 13-18 сентября 2009 г.) : в 2-х ч. / отв. ред. Н. Г. Очирова. Элиста : НПП «Джангар». Ч. 1. 445 с. С. 89-93.

Бадмаева, Т. Б. (1992) Невербальные формы общения в традиционном быту калмыков // VI Международный конгресс монголоведов. Улан-Батор, август 1992. Доклады российской делегации. М. : Институт востоковедения. С. 3-7.

Базен, Л. (1986) Человек и понятие истории у тюрков Центральной Азии в VIII в. // Зарубежная тюркология : сб. / пер. с англ., нем., фр. / сост. и авт. предисл. С. Г. Кляшторный. Вып. 1. Древние тюркские языки и литературы. М. : Наука. 383 с. С. $345-360$.

Баринова, Е. Б. (2013) Этнокультурные контакты Китая с народами Центральной Азии в древности и средневековье. М. : ИЭА РАН. 419 с.

Батмаев, М. М. (1993) Калмыки в XVII-XVIII веках. События, люди, быт. Элиста : АПП «Джангар». 382 с.

Деготькова, И. (2018) Власти добрались до самозанятых: как отобрать доходы у 20 миллионов россиян [Электронный ресурс] // Московский комсомолец. 1 апреля. URL: http://www.mk.ru/economics/2018/04/01/vlasti-dobralis-do-samozanyatykh-kak-otobrat-dokhody-u-20-millionov-rossiyan.html (дата обращения: 2.04.2018 г.).

Даргын-оол, Ч. К. (2006) Проблемы модернизации Тувы // IX Международный конгресс монголоведов. Улан-Батор, 8-12 август 2006. Доклады российских ученых. М. : Товарищество научных изданий КМК. 366 с. С. 48-54.

Дашибалов, Б., Рассадин, В.(2004) Откуда вышли предки монголов? // Восточная коллекция. № 4 (19). С. 35-41.

Добренко, Е. (2007) Политэкономия соцреализма. М.: Новое литературное обозрение. 592 с.

Дробышев, Ю.И. (2006) О природопользовании ранних монголов // IX Международный конгресс монголоведов. Улан-Батор, 8-12 август 2006 г. Доклады российских ученых. М. : Товарищество научных изданий КМК. 366 с. С. 54-62. 
Дробышев, Ю. И. (2014) Человек и природа в кочевых обществах Центральной Азии (III до н. э. - XVI в. н. э.). М.: Институт востоковедения РАН. 604 с.

Дробышев, Ю. И., Гунин П. Д., Бажа, С. Н. (2008) Роль буддизма как регулятора природопользования на разных этапах социально-экономического развития Монголии // Буддийская культура: история, источниковедение, языкознание и искусство: Вторые Доржиевские чтения / отв. ред. А. О. Бороноев. СПб. : СанктПетербургское востоковедение. 368 с. С. 121-136.

Евразийский мир: ценности, константы, самоорганизация (2010) / отв. ред. Ю. В. Попков. Новосибирск: Нонпарель. 449 с.

Жанисов, А. Т. (2002) Коневодство как один из основных системообразующих факторов зарождения и развития номадизма в степях Евразии // Материальные и духовные основы калмыцкой государственности в составе России (к 360-летию со дня рождения Аюки-хана): Материалы международной научной конференции : в 2-х ч. / отв. ред. Г. М. Борликов. Элиста: КалмГУ. Ч. 2. 156 с. С. 88-90.

Козлова, Н. Н. (1999) Социально-историческая антропология. М. : Ключ-С. 192 c.

Кознова И. (1997) Традиции и новации в поведении современных крестьян // Идентичность и конфликт в постсоветских государствах / под. ред. М. Б. Олкотт, В. Тишкова, А. Малашенко. М.: Моск. Центр Карнеги. 490 с. С. 359-382.

Крадин, Н. Н., Скрынникова, Т. Д. (2006) Империя Чингис-хана. М. : Восточная литература. 557 с.

Кызласов, Л. Р. (1975) Ранние монголы (к проблеме истоков средневековой культуры) // Сибирь, Центральная и Восточная Азия в средние века. История и культура Востока Азии. Т. ІІІ / отв. ред. В. Е. Ларичев. Новосибирск : Наука. 236 с. C. $170-177$.

Кызласов, Л. Р. (1984) История Южной Сибири в средние века. М. : Высшая школа. 167 с.

Кычанов, Е. И. (1980) Монголы в VI - первой половине XII в. // Дальний Восток и соседние территории в средние века / отв. ред. В. Е. Ларичев. Новосибирск : Наука. 236 с. С. $136-148$.

Ламажаа, Ч. К. (2013) Архаизация общества. Тувинский феномен. М. : Книжный дом «Либроком». 272 с.

Мак-Нил, У. (2004) Восхождение Запада: История человеческого сообщества / пер. с англ. Киев : Ника-центр; М. : Старклайт. 1063 с.

Масанов, Н. Э. (1995) Кочевая цивилизация казахов (основы жизнедеятельности номадного общества). Алматы : Социнвест ; М. : Горизонт. 320 с. 
Материалы по истории древних кочевых народов группы дунху (1984) / пер. кит. источников / отв. ред. Н. Ц. Мункуев; введ., пер. и коммент. В. С. Таскина. М. : Наука. 486 с.

Нанзатов, Б. 3. (2010) Традиционные формы хозяйствования бурят и особенности организации труда как пример адаптации в условиях модернизационных процессов // Глобализация и монгольский мир : сб. статей по материалам Международной научной конференции, проведенной 15-18 июля 2010 г. [в рамках IV Заседания Генеральной сессии Конвента монголов мира в Улан-Удэ] / гл. ред. Б. В. Базаров. Улан-Удэ : Конвент монголов мира [и др.]. 387 с. С. 73-77.

Отходники (2013) / Плюснин Ю. М. и др. М. : Новый Хронограф. 376 с.

Потаев, В. С. (2011) Из опыта развития монгольского пастбищного животноводства // Сотрудничество Монголии и Бурятии (Россия) в свете обеспечения безопасности в ШОС: мат-лы междунар. семинара / отв. ред. Ю. В. Попков. Улан-Удэ : Изд-во БНЦ СО РАН. 150 с. С. 69-77.

Рахманалиев, Р. (2009) Империя тюрков: великая цивилизация. М.: РИПОЛ классик. 709 с.

Содномпилова, М. М. (2002) Рациональное и символическое в строительной традиции бурят // VIII Международный конгресс монголоведов (Улан-Батор, 5-12 августа 2002 г.) доклады российской делегации / отв. ред. Р. Б. Рыбаков. М. : «Гуманитарий» Академия гум. исследований. 302 с. С. 122-128.

Сусеева, Д. А. (2003) Письма хана Аюки и его современников (1714-1724: опыт лингвосоциологического исследования. Элиста : АПП «Джангар». 456 с.

Ткачев, В. Н. (1986) Каракорум в XIII веке // Mongolica : Памяти академика Бориса Яковлевича Владимирцова, 1884-1931 : сборник статей / редкол.: А. Н. Кононов (пред.) и др. М. : Наука. 301 с. С. 219-231.

Франке, Н. С. (2008) Порядок трудоустройства безработных на верхнеудинской бирже труда // Сибирские чтения в РГГУ. Альманах. Вып. 3. М.: РГГУ. С. 155-160.

Хэмфри, К. (2010) Постсоветские трансформации в азиатской части России (антропологические очерки) / пер. с англ. М.: Наталис. 384 с.

Чимидов, Т. А. (2009) Система использования и меры ухода за пастбищным полем // Материалы Международной научной конференции «Единая Калмыкия в единой России: через века в будущее», посвященной 400-летию добровольного вхождения калмыцкого народа в состав российского государства (г. Элиста, 13-18 сентября, 2009, г.) : в 2-х ч. / отв. ред. Н. Г. Очирова. Элиста: НПП «Джангар». Ч. 2.648 с. С. $483-487$.

Шубин, В. Ф. (1953) Земледелие Монгольской Народной Республики. М. : Издво АН СССР. 347 с. 
Шюц, А. (1988) Структура повседневного мышления // Социологические исследования. № 2. С. 129-137.

Gardner, G. (2010) Engaging Religions to Shape Worldviews [Электронный pecypc]// State of the World 2010: Transforming Cultures: From Consumerism to Sustainability. P. 20-29. URL: http://blogs.worldwatch.org/transformingcultures/wpcontent/uploads/2009/04/Engaging-Religions-to-Shape-Worldviews-Gardner.pdf (дата обращения: 28.02.2018).

Grousset, R. (1970) The Empire of Steppes. A History of Central Asia / Transl. from French by N. Walford. Rutgers University. 687 p.

Humphrey, C. (1983) Karl Marx Collective: economy, society and religion in a Siberian collective farm. Cambridge : Cambridge University Press. 516 p.

Lane, G. (2006) Daily life in the Mongol empire. Greenwood Press, Westport, CT. $312 \mathrm{p}$.

Nierenberg, D. (2007) Meat Output and Consumption Grow [Электронный pecypc] //Vital Sings. The Trends That Are Shaping Our Future. P. 24-26. URL: http:// www.worldwatch.org/files/pdf/Vital\%20Signs\%202007-2008.pdf (дата обращения: 28.02.2018).

Weatherford, J. (2010) The Secret History of Mongol Queens. How the Daughter of Genghis Khan rescued His Empire. New York : Broadway Paperbacks. 318 p.

Дата поступления: 13.04.2018 2.

\section{REFERENCES}

Atanov, N. I. (2010) Transformatsiia khoziaistvennogo uklada mongo-loiazychnykh narodov Iuzhnoi Sibiri [Transformation of Southern Siberia Mongolian-speaking Peoples' Economic Structure]. In: Globalizatsiia i mongol'skii mir : sb. statei po materialam Mezhdunarodnoi nauchnoi konferentsii, prove-dennoi 15-18 iiulia 2010 g. (v ramkakh IV Zasedaniia General'noi sessii Konventa mongolov mira v Ulan-Ude) [Globalization and the Mongolian World: Proceedings of the International Scientific Conference held on July 15-18, 2010 (within the IV Session of the General Session of the Mongolian Convention in Ulan-Ude] / Ed. by B. V. Bazarov. Ulan-Ude, s. n. 387 p. Pp. 35-39. (In Russ.).

Badmaev, V. N. (2007) Kochevaia kul'tura kak faktor khoziaistvennoi zhizni kalmytskogo etnosa [Nomadic culture as a factor of Kalmyk economic life]. Vestnik Kalmytskogo regional'nogo otdeleniia Rossiiskogo filosofskogo obshchestva, no. 1, pp. 7-12. (In Russ.).

Badmaeva, E. N. (2009) Povolzhskaia kolonizatsionno-meliorativnaia ekspeditsiia v Kalmykii perioda NEPa [The Volga colonization and land improvement expedition in Kalmykia during the NEP]. In: Materialy Mezhdunarodnoi nauchnoi konferentsii «Edinaia Kalmykiia v edinoi Rossii: cherez veka v budushchee», posviashchennoi 400-leti- 
iu dobrovol'nogo vkhozhdeniia kalmytskogo naroda $v$ sostav rossiiskogo gosudarstva (g. Elista, 13-18 sentiabria 2009 g.) [Proceedings of the International Scientific Conference "The United Kalmykia in the Unified Russia: Through the centuries to the Future", dedicated to the 400th anniversary of the voluntary entry of the Kalmyk people into the Russian state (Elista, September 13-18, 2009)] : in 2 vols. / ed. by N. G. Ochirov. Elista, NPP «Dzhangar». Vol. 1.445 p. Pp. 89-93. (In Russ.).

Badmaeva, T. B. (1992) Neverbal'nye formy obshcheniia v traditsionnom bytu kalmykov [Nonverbal forms of communication in the Kalmyk traditional lifestyle]. In: VI Mezhdunarodnyi kongress mongolovedov. Ulan-Bator, avgust 1992. Doklady rossiiskoi delegatsii [6th International Congress of the Mongolists. Ulan-Bator, August 1992. Presentations of the Russian delegation]. Moscow, Institut vostokovedeniia. Pp. 3-7. (In Russ.).

Bazen, L. (1986) Chelovek i poniatie istorii u tiurkov Tsentral'noi Azii v VIII v. [Man and the concept of history among the Turks of Central Asia in the 8th century]. In: $\mathrm{Za}$ rubezhnaia tiurkologiia [Turkic studies abroad] : collected papers / Transl. from Engl., Germ., Fr. / comp. and pref. by S. G. Kliashtornyi. Vol. 1. Drevnie tiurkskie iazyki i literatury. Moscow, Nauka. 383 p. Pp. 345-360. (In Russ.).

Barinova, E. B. (2013) Etnokul'turnye kontakty Kitaia s narodami Tsentral'noi Azii v drevnosti i srednevekov'e [Chinese ethnocultural contacts with the peoples of Central Asia in the ancient times and the Middle Ages]. Moscow, IEA RAN. 419 p. (In Russ.).

Batmaev, M. M. (1993) Kalmyki v XVII-XVIII vekakh. Sobytiia, liudi, byt [Kalmyks in the 17th and 18th centuries. Events, people, everyday life]. Elista, APP «Dzhangar». 382 p. (In Russ.).

Degot'kova, I. (2018) Vlasti dobralis' do samozaniatykh: kak otobrat' dokhody u 20 millionov rossiian [Authorities focus on the self-employed: how to tax revenues of 20 million Russians]. Moskovskii komsomolets, April 1 [online] Available at: http://www. mk.ru/economics/2018/04/01/vlasti-dobralis-do-samozanyatykh-kak-otobrat-dokhody-u-20-millionov-rossiyan.html (access date: 2.04.2018). (In Russ.).

Dargyn-ool, Ch. K. (2006) Problemy modernizatsii Tuvy [Problems of modernization in Tuva]. In: IX Mezhdunarodnyi kongress mongolovedov. Ulan-Bator, 8-12 avgust 2006. Doklady rossiiskikh uchenykh [IX International Congress of Mongolists. Ulan-Bator, August 8-12, 2006. Presentations of Russian researchers]. Moscow, Tovarishchestvo nauchnykh izdanii KMK. 366 p. Pp. 48-54. (In Russ.).

Dashibalov, B. and Rassadin V. (2004) Otkuda vyshli predki mongolov? [Where did the ancestors of Mongols come from?]. Vostochnaia kollektsiia, no. 4 (19), pp. 35-41. (In Russ.).

Dobrenko, E. (2007) Politekonomiia sotsrealizma [The political economy of the socialist realism]. Moscow, Novoe literaturnoe obozrenie. 592 p. (In Russ.).

Drobyshev, Iu. I. (2006) O prirodopol'zovanii rannikh mongolov [On the uses of nature by the early Mongols]. In: IX Mezhdunarodnyi kongress mongolovedov. Ulan-Ba- 
tor, 8-12 avgust 2006. Doklady rossiiskikh uchenykh [IX International Congress of Mongolists. Ulan-Bator, August 8-12, 2006. Presentations of Russian researchers]. Moscow, Tovarishchestvo nauchnykh izdanii KMK. 366 p. Pp. 54-62. (In Russ.).

Drobyshev, Iu. I. (2014) Chelovek i priroda v kochevykh obshchestvakh Tsentral'noi Azii (III do n. e. $-X V I$ v. n. e.) [Man and nature in the nomadic societies of Central Asia (3rd century $B C-16$ th century $A D$ ]. Moscow, Institut vostokovedeniia RAN. 604 p. (In Russ.).

Drobyshev, Iu. I., Gunin P. D. and Bazha, S. N. (2008) Rol' buddizma kak reguliatora prirodopol'zovaniia na raznykh etapakh sotsial'no-ekonomicheskogo razvitiia Mongolii [Buddhism as the regulator of environmental management at different stages of the socio-economic development of Mongolia]. In: Buddiiskaia kul'tura: istoriia, istochnikovedenie, iazykoznanie i iskusstvo: Vtorye Dorzhievskie chteniia [Buddhist Culture: History, Source Studies, Linguistics and Art: 2nd Dorzhiev Readings] / ed. by A. O. Boronoev. St. Petersburg, Sankt-Peterburgskoe vostokovedenie. 368 p. Pp. 121-136. (In Russ.).

Evraziiskii mir: tsennosti, konstanty, samoorganizatsiia [Eurasian world: values, constants, self-organization] (2010) / ed. by Iu. V. Popkov. Novosibirsk, Nonparel'. 449 p. (In Russ.).

Zhanisov, A. T. (2002) Konevodstvo kak odin iz osnovnykh sistemoob-razuiushchikh faktorov zarozhdeniia i razvitiia nomadizma v stepiakh Evrazii [Horse breeding as one of the main system-forming factors of the origin and development of nomadism in the Eurasia steppes]. In: Material'nye i dukhovnye osnovy kalmytskoi gosudarstvennosti $v$ sostave Rossii (k 360-letiiu so dnia rozhdeniia Aiuki-khana): Materialy mezhduna-rodnoi nauchnoi konferentsii [Material and spiritual foundations of the Kalmyk statehood as a part of Russia (for the 360th Anniversary of Ayuki Khan): Proceedings of international conference] : in 2 vols. / ed. by G. M. Borlikov. Elista, KalmGU. Vol. 2. 156 p. Pp. 88-90. (In Russ.).

Kozlova, N. N. (1999) Sotsial'no-istoricheskaia antropologiia [Socio-historical anthropology]. Moscow, Kliuch-S. 192 p. (In Russ.).

Koznova I. (1997) Traditsii i novatsii v povedenii sovremennykh krest'ian [Traditions and innovations in modern peasants' behavior]. In: Identichnost' $i$ konflikt $v$ postsovetskikh gosudarstvakh [Identity and Conflict in Post-Soviet States] / ed. by M. B. Olkott, V. Tishkova and A. Malashenko. Mocow, Mosk. Tsentr Karnegi. 490 p. Pp. 359-382. (In Russ.).

Kradin, N. N. and Skrynnikova, T. D. (2006) Imperiia Chingis-khana [The empire of Genghis Khan]. Moscow, Vostochnaia literatura. 557 p. (In Russ.).

Kyzlasov, L. R. (1975) Rannie mongoly (k probleme istokov sredne-vekovoi kul'tury) [Early Mongolians: On the issue of the origins of medieval culture]. In: Sibir', Tsentral'naia i Vostochnaia Aziia v srednie veka. Istoriia i kul'tura Vostoka Azii [Siberia, 
Central and Eastern Asia in the Middle Ages. History and culture of East Asia. Vol. III] / Ed. by V. E. Larichev. Novosibirsk, Nauka. Vol. III. 236 p. Pp. 170-177. (In Russ.).

Kyzlasov, L. R. (1984) Istoriia Iuzhnoi Sibiri v srednie veka [History of Southern Siberia in the Middle Ages]. Moscow, Vysshaia shkola. 167 p. (In Russ.).

Kychanov, E. I. (1980) Mongoly v VI - pervoi polovine XII v. [Mongols from the 6th to the first half of the 12th century]. In: Dal'nii Vostok i sosednie territorii v srednie veka [Far East and neighboring territories in the Middle Ages] / Ed. by V. E. Larichev. Novosibirsk, Nauka. 236 p. Pp. 136-148. (In Russ.).

Lamazhaa, Ch. K. (2013) Arkhaizatsiia obshchestva. Tuvinskii fenomen [Archaization of the society: the Tuvan phenomenon]. Moscow, Knizhnyi dom «Librokom». 272 p. (In Russ.)

McNeill, W. (2004) Voskhozhdenie Zapada: Istoriia chelovecheskogo so-obshchestva [The Rise of the West: The history of the human community] / Transl. from Engl. Kiev, Nika-tsentr; Moscow, Starklait. 1063 p. (In Russ.)

Masanov, N. E. (1995) Kochevaia tsivilizatsiia kazakhov (osnovy zhizne-deiatel'nosti nomadnogo obshchestva) [Nomadic civilization of Kazakhs: foundations of the vital activity of a nomadic society)]. Almaty, Sotsinvest; Moscow, Gorizont. 320 p. (In Russ.)

Materialy po istorii drevnikh kochevykh narodov gruppy dunkhu [Sources on the history of the ancient nomadic peoples of the Donghu group] (1984) / Translations of Chinese sources / Ed. by N. Ts. Munkuev; Introduction, translation and commentary by V. S. Taskin. Moscow, Nauka. 486 p. (In Russ.)

Nanzatov, B. Z. (2010) Traditsionnye formy khoziaistvovaniia buriat i osobennosti organizatsii truda kak primer adaptatsii v usloviiakh moderni-zatsionnykh protsessov [Buryat traditional forms of economic management and the distinctions of the work organization as an example of adaptation to the modernization process]. In: Globalizatsiia i mongol'skii mir : sb. statei po materialam Mezhdunarodnoi nauchnoi konferentsii, provedennoi 15-18 iiulia 2010 g. (v ramkakh IV Zasedaniia General'noi sessii Konventa mongolov mira $v$ Ulan-Ude) [Globalization and the Mongolian World: Proceedings of the International Scientific Conference held on July 15-18, 2010 (within the IV Session of the General Session of the Mongolian Convention in Ulan-Ude] / Ed. by B. V. Bazarov. Ulan-Ude, s. n. 387 p. Pp. 73-77. (In Russ.)

Otkhodniki [Seasonal workers] (2013) / Pliusnin Iu. M. et al. Moscow, Novyi Khronograf. 376 p. (In Russ.)

Potaev, V. S. (2011) Iz opyta razvitiia mongol'skogo pastbishchnogo zhivotnovodstva [From the experience of the development of Mongolian pasture livestock breeding]. In: Sotrudnichestvo Mongolii i Buriatii (Rossiia) v svete obespecheniia bezopasnosti v ShOS: mat-ly mezhdunar. seminara [Collaboration of Mongolia and Buryatia (Russia) in the light of ensuring security of the SCO: proceedings of the international. workshop] / ed. by Iu. V. Popkov. Ulan-Ude, Izd-vo BNTs SO RAN. 150 p. Pp. 69-77. (In Russ.) 
Rakhmanaliev, R. (2009) Imperiia tiurkov: velikaia tsivilizatsiia [Empire of the Turks: the great civilization]. Moscow, RIPOL klassik. 709 p. (In Russ.)

Sodnompilova, M. M. (2002) Ratsional'noe i simvolicheskoe v stroi-tel'noi traditsii buriat [Rational and symbolic in the Buryat construction tradition]. In: VIII Mezhdunarodnyi kongress mongolovedov (Ulan-Bator, 5-12 avgusta 2002 g.) doklady rossiiskoi delegatsii [8th International Congress of Mongolists (Ulan-Bator, August 5-12, 2002), Presentations of the Russian delegation] / ed. by R. B. Rybakov. Moscow, «Gumanitarii» Akademiia gum. issledovanii. 302 p. Pp. 122-128. (In Russ.)

Suseeva, D. A. (2003) Pis'ma khana Aiuki i sego sovremennikov (1714-1724: opyt lingvosotsiologicheskogo issledovaniia [The letters of Ayuka Khan and his contemporariesrs (1714-1724): an attempt at a linguosociological study]. Elista, APP «Dzhan-gar». 456 p. (In Russ.)

Tkachev, V. N. (1986) Karakorum v XIII veke [Karakorum in the 13th century]. In: Mongolica : Pamiati aka-demika Borisa Iakovlevicha Vladimirtsova, 1884-1931 [Mongolica : in the memory of Boris Yakovlevich Vladimirtsov, FRAS, 1884-1931] : collected papers / Editor-in-Board: A. N. Kononov (preface) et al. Moscow, Nauka. 301 p. Pp. 219-231. (In Russ.)

Franke, N. S. (2008) Poriadok trudoustroistva bezrabotnykh na verkh-neudinskoi birzhe truda [The method of employment of the unemployed at the Verkhneudinsky Employment Bureau]. In: Sibirskie chteniia v RGGU. Almanac. Vol. 3. Moscow, RGGU. Pp. 155-160. (In Russ.)

Humphrey, C. (2010) Postsovetskie transformatsii v aziatskoi chasti Rossii (antropologicheskie ocherki) [Post-Soviet transformations in the Asian part of Russia: Essays in anthropology]. Transl. from Engl. Moscow, Natalis. 384 p. (In Russ.)

Chimidov, T. A. (2009) Sistema ispol'zovaniia i mery ukhoda za past-bishchnym polem [System of use and modes of pasture field care]. In: Materialy Mezhdunarodnoi nauchnoi konferentsii «Edinaia Kalmykiia v edinoi Rossii: cherez veka $v$ budushchee», posviashchennoi 400-letiiu dobrovol'nogo vkhozhdeniia kalmytskogo naroda v sostav rossiiskogo gosudarstva (g. Elista, 13-18 sentiabria, 2009 g.) [Proceedings of the International Scientific Conference "The United Kalmykia in the Unified Russia: Through the centuries to the Future", dedicated to the 400th anniversary of the voluntary entry of the Kalmyk people into the Russian state (Elista, September 13-18, 2009)] : in 2 vol. / Ed. by N. G. Ochirov. Elista, NPP «Dzhangar». Vol. 2.648 p. Pp. 483-487. (In Russ.)

Shubin, V. F. (1953) Zemledelie Mongol'skoi Narodnoi Respubliki [Agriculture of the Mongolian People's Republic]. Moscow, Izd-vo AN SSSR. 347 p. (In Russ.)

Schutz, A. (1988) Struktura povsednevnogo myshleniia [Structure of the everyday thinking]. Sotsiologicheskie issledovaniia, no. 2, pp. 129-137. (In Russ.)

Gardner, G. (2010) Engaging Religions to Shape Worldviews. State of the World 2010: Transforming Cultures: From Consumerism to Sustainability. P. 20-29 [online] Available 
at: http://blogs.worldwatch.org/transformingcultures/wp-content/uploads/2009/04/ Engaging-Religions-to-Shape-Worldviews-Gardner.pdf (access date: 28.02.2018).

Grousset, R. (1970) The Empire of Steppes. A History of Central Asia / Transl. from French by N. Walford. Rutgers University. 687 p.

Humphrey, C. (1983) Karl Marx Collective: economy, society and religion in a Siberian collective farm. Cambridge, Cambridge University Press. 516 p.

Lane, G. (2006) Daily life in the Mongol empire. Greenwood Press, West-port, CT. $312 \mathrm{p}$.

Nierenberg, D. (2007) Meat Output and Consumption Grow. Vital Sings. The Trends That Are Shaping Our Future. P. 24-26 [online] Available at: http://www.worldwatch. org/files/pdf/Vital\%20Signs\%202007-2008.pdf (access date: 28.02.2018).

Weatherford, J. (2010) The Secret History of Mongol Queens. How the Daughter of Genghis Khan rescued His Empire. New York, Broadway Paper-backs. 318 p.

Submission date: 13.04.2018.

\section{Для цитирования:}

Четырова Л. Б. Труд в этнической культуре кочевников постсоциализма (на примере бурят, калмыков, тувинцев) [Электронный ресурс] // Новые исследования Тувы. 2018, № 2. URL: https://nit.tuva.asia/nit/article/view/770 (дата обращения: дд.мм. гг.). DOI: $10.25178 /$ nit.2018.2.3

\section{For citation:}

Chetyrova L. B. Labor in post-socialist ethnic culture: the cases of Buryats, Kalmyks and Tuvans. The New Research of Tuva, 2018, no. 2 [on-line] Available at: https://nit.tuva. asia/nit/article/view/770 (accessed:...). DOI: 10.25178/nit.2018.2.3 